\title{
Variantangivelser i en dansk produktionsordbog ud fra eksempler med fleksionsangivelser i Retskriv- ningsordbogen 1
}

\begin{abstract}
Looking at articles on language in the newspapers, you will find it striking how many readers are interested in the permissibility of certain expressions. How can we decide if a word or an inflection is allowed? Some people think that the use gives the necessary answers, while others are of the opinion that the customs and especially the language customs are degenerating and therefore cannot serve as decision maker. More than 270 years ago this battle was fought under the watchwords: usus tyrannus and usus imperans. This was of course not the first attempt to define the differences between descriptive and prescriptive linguistics, and it was indeed not the last one. Despite of that now no really convincing solutions have been given until now. This is due not only to different opinions on the relation between the use of the language and its rules, but also to the following factors: (a) the empirical basis of the description, and (b) the aim of the description.

In this article it will be shown that purely descriptive information does not help clearly enough by problems on language production, and that extremely prescriptive information helps too little by problems on language reception. In other words, we need prescriptive rules for production and descriptive ones for reception. For this form of prescription which builds on a selection on descriptive data we introduce the expression proscription.
\end{abstract}

\section{Smag, behag og ubehag}

I Jyllands-Posten blev der den 21.12.1997 aftrykt følgende spørgsmål fra en læser i Vejle:

For tiden læser jeg en bog, hvor forfatteren i sin omtale af nogle sypiger skriver, at pigerne fnes. Jeg har altid troet, at der hedder fnis, fniser, fnisede, men er kommet i tvivl om, hvilken bøjning er den rigtige.

1 Denne artikel bygger på Bergenholtz 1998. I dette bidrag fokuseres til forskel fra denne artikel på leksikografisk teori og praksis for dansk, specielt med henblik på monolingval dansk leksikografi.

* Henning Bergenholtz

Handelshфjskolen i Århus

Fuglesangs Allé 4

DK-8210 Århus V 
Avisens svar rummer en indirekte kritik af den form for liberalitet, som kendetegner Dansk Sprognævn: Bortset fra få tilsyneladende noget tilfældige kæpheste tillades alt, som en fra nævnet har hørt eller læst eller har hørt at nogen har hørt eller læst:

I datid er der hele tre muligheder at vælge imellem: fnisede, fniste - og fnes. I førnutid er der til gengæld kun to: fniset eller fnist. Man kan altså sige Jeg fnes, men endnu ikke Jeg har fneset.

Nogle ord er elementært grimme, både i udtale og på tryk. Smag og behag er jo forskellig, men mon ikke de fleste kan være enige om, at fnes, der blev anerkendt med Retskrivningsordbogens 1986-udgave, er et afskyeligt ord?

Jeg tilslutter mig slutbemærkningen i Deres brev: "fnes falder mig lidt svært".

Også mig, vil jeg tilføje, men her må en lingvist af hankøn udtale sig med forsigtighed, fordi der muligvis foreligger en væsentlig forskel i brugen af disse verber i relation til mænd og til kvinder, herom senere $\mathrm{i}$ bidraget. Avisen holder sig til Retskrivningsordbogen (herefter RTO), som i den nye retskrivningslov, der med gyldighed fra august 1997 har givet lovmæssig autoritet Dansk Sprognævn og dermed også til RTO. I denne ordbog finder vi følgende oplysninger om fleksion af dette verbum:

fnise, -ede $e l$. -te $e l$. fnes, fniset $e l$. fnist.

Alt i alt tillades således følgende 8 former, hvoraf tre for præteritum og to for particip perfekt: fnis, fnise, fniser, fnisede, fniste, fnes, fniset, fnist.

Tilsvarende varianter findes på hver eneste side i Danmarks liberale retskrivningsautoritet, RTO:

misbrug -en $e l$. -et, misbrug -ene

Ikke bare for grundordet, men også for en række komposita som fx alkoholmisbrug, embedsmisbrug, kokainmisbrug og magtmisbrug må derfor gælde, at man lige så godt kan skrive en eller et misbrug, men også misbruget og misbrugen. På lignende vis er en række varianter tilladt i fx følgende tilfælde i RTO:

aftenen/aftnen, aftener/aftner, aftenerne/aftnerne

morgenen/morgnen, morgener/morgner, morgenerne/morgnerne

publikumet/publikummet

katalogen/kataloget

bægeret/bægret, bægere/bægre, bægerne/bægrene 
nævnede/nævnte

menneskene/menneskerne

kratere/kratre, kraterne/kratrene

en/et sammenhæng, sammenhængen/sammenhænget, sammenhænge/ sammenhæng

kursuset/kursusset/kurset, kursus/kurser, kursusene/kursussene/kurserne

I sidstnævnte eksempel må man spørge sig selv, hvorfor kursus(s)er ikke også er medtaget, - når vi nu er i gang. Det har jeg hørt en del gange, men det er ikke den normalt brugte fleksionsform. I dette og alle andre af de her nævnte tilfælde viser sprogbrugen i praksis en klar præference for bestemte varianter, hvorimod andre enten næsten aldrig bruges, eller først og fremmest i talesprog, men ikke i skrevet sprog. Men man kan jo ikke altid gå efter beskrivelse i korpus, det kan være for lille. Man kan her enten bruge belæg fra seddelsamlinger, eller endnu bedre have et større korpus, men først og fremmest vil det være rimeligt at drage analogislutninger, som vil føre til en ensartet sprogbrug og en lettere brug af en ordbog, sml. følgende varianter fra RTO, hvor meget taler for at vælge den første variant:

midlet/middelet

musklen/muskelen

strimlen/strimmelen

$\mathrm{m} ø \mathrm{blet} / \mathrm{m} \varnothing \mathrm{belet}$

kitlen/kittelen

kartoflen/kartoffelen

hvirvlen/hvirvelen

cirklen/cirkelen

kuplen/kuppelen

længslen/længselen

manglen/mangelen

Men i en mindre del af analoge tilfælde må man ved forslag til produktion dog tage højde for sprogpraksis, ellers kan man ende i en situation, hvor der er en for stor diskrepans mellem deskription hhv. forslag til produktion og den normale sprogbrug. I følgende tilfælde vil man ikke kunne anbefale brugen af den ene eller den anden variant:

handelen/handlen

regelen/reglen

forbudet/forbuddet, forbudene/forbuddene 
Når det drejer sig om visse faste ordforbindelser vælger RTO ligeledes at anse begge varianter for lige anbefalelsesværdige:

i steden for/i stedet for

Dette valg er måske mindre overbevisende end ved forbudet/forbuddet. $\mathrm{Vi}$ vender tilbage til problemet. I første omgang genoptager vi diskussionen om fnisede, fniste og fnes. Nogle brugere af en stor dansk ordbog vil måske slet ikke vide, hvad fnise hedder i præteritum. Så er det nok en skoleelev. De fleste halvvoksne eller voksne danskere vil kende to eller måske alle tre muligheder. En sådan brugers problem er, at han gerne vil have at vide, hvilken af mulighederne han skal bruge. Hvis der i ordbogen kun står en af dem, vil han vælge den. Hvis der stod, at fnes er et tilladt, men afskyeligt ord, ville de fleste brugere sikkert undgå det.

Der foreligger her store forskelle mellem holdningen til sproget. I Danmark er der tradition for det, jeg senere kalder usus imperans, brugens magt. Når man sammenligner de forskellige udgaver af RTO, kan man se, at de tillader flere og flere varianter - ligesom vi før hørte det om fnes, som har været tilladt siden 1986. Samtidig er der en tendens til at beholde forhåndenværende former, selv om de ikke mere bruges, eller næsten ikke bruges. Erik Hansen skriver om dette problem i Mål \& Mæle 3, fra november 1997. Her drejer det sig om $i$ stedet for eller $i$ steden for. Begge er tilladt af Dansk Sprognævn og forsvares bravt:

Mange kan ikke acceptere udtrykket $i$ steden for. Det er igen et eksempel på at den gamle form lægges for had. I steden for er et minde om dengang det hed en sted. Naturligvis er $i$ stedet for også korrekt, men ligefrem at fors $\varnothing$ ge at udrydde den gamle form er brutalt og pietetsløst. (Hansen 1997:30).

Det kan jeg godt lide: "brutalt og pietetsløst". Holdningen svarer til den danske tradition med en stærk deskriptiv tendens i sprogvidenskaben, hvilket man i denne sammenhæng i øvrigt ikke gør i samme grad i Sverige, endnu mindre i Norge og på Færøerne, og slet ikke på Island. På den anden side synes jeg nok, at man også godt kunne have vendt det om: Den sprogbruger, som er usikker på, han nu skal skrive $i$ steden for eller $i$ stedet for, bliver dog brutalt ladt i stikken ved at få overladt problemet til eget frit valg.

Man kan som Jyllands-Posten i et svar på et andet læserbrev den 9.2.1997 i sammenhæng med valg mellem faren og faderen gøre op- 
mærksom på, at en ordbog ikke er et orakel, som man uden indskrænkninger skal følge overalt:

man skal være varsom med at skrive faren og moren. De to ord vækker anstød hos mange, og hvorfor så bruge dem, selv om de står i ordbogen? (Nielsen 1997)

Det sidste retoriske spørgsmål kan vække leksikografens dårlige samvittighed: Hvorfor er der ingen ordbog, der fortæller ordbogsbrugeren, at han eller hun i bestemte situationer evt. bør undgå brugen af potentielle anstødssten? Nu er det ikke helt rigtigt, at der slet ikke findes sådanne ordbøger, men det er ikke mange. En af undtagelserne er AHD, som har rådspurgt en brugerkommission (Usage Panel) af 100 prominente US-amerikanere om deres holdning til en række sproglige tvivlstilfælde. Man kan fx slå op under either og søge information om problemet personkongruens mellem subjekt og finit verbum:

Either takes a singular verb: Either plant grows in the shade. Sometimes it is used informally with a plural verb, especially when followed by of and a plural: I doubt whether either of them are available. But such use is unaccceptable in formal writing to a majority of the Usage Panel.

Om ordbogen gennem inddragelse af sådanne svar bliver "more precisely descriptive" (AHD, Introduction, side 7), kan drages i tvivl, når man sammenligner denne udgave af AHD med en tidligere. I den første udgave fra 1969 var man måske ikke mere deskriptiv, men helt sikkert mere informativ, idet man fortalte, at $92 \%$ af Usage Panel afviste pluralformen i sætningen med either. Også selv om den afviste form i den sproglige praksis måtte være omtrent så hyppig som den foretrukne singularform, ville man fx i en ansøgning undgå at bruge den form, der ikke vækker anstød i Usage Panel og dermed også blandt typiske beslutningstagere.

\section{Usus tyrannus contra usus imperium}

Normproblematikken er hverken i videnskabelig argumentation eller i praksis et af de temaer, hvor man kan forvente, at der vil kunne opnås et afsluttende videnskabeligt svar. Grunden er ikke, at normproblematikken ikke er blevet eller ikke vil blive behandlet i udstrakt grad i den videnskabelige diskussion. Tværtimod har vi her et af de temaer, som der er skrevet særligt meget om. Alene den foreliggende litteratur vil 


\section{0}

sikkert kunne fylde et mindre bibliotek, sml. hertil som en begyndelse en ældre, men udmærket bibliografi til emnet, hvis 1372 titler let ville kunne mangedobles (Gröschel 1982). Min pessimisme har flere grunde:

1. Temaet er blevet behandlet igen og igen i mange hundrede år. Men hver ny generation begynder tilsyneladende næsten helt forfra på diskussionen.

2. Der foreligger ingen klarhed og enighed om betydningen af termerne deskription og præskription.

3. Den vigtigste grund herfor er uden tvivl, at de forskellige definitioner af præskription ofte påvirkes af den holdning, forskellige lingvister har i relation til enhver tids ændringer i sprogbrugen og til sproglige påbud og sproglige forbud. Desuden påvirkes definitionen af deskription af opfattelsen af den empiriske basis, som danner eller bør danne udgangspunkt for beskrivelser.

4. Endelig kan man se, at holdninger til sprogbrug ofte er forbundet med stærke følelser. "Leave my language alone" siger det ene hold. "Den ændring eller nyskabelse vil jeg ikke finde mig i" og "Følgende ændringer, reguleringer og nyskabelser er nødvendige" siger det andet hold.

De største uoverensstemmelser opstår normalt i almensproglig sammenhæng. Med visse undtagelser er der blandt fagleksikografer hhv. terminografer enighed om, at den størst mulige normering til hjælp for en entydig fagkommunikation er ønskværdig. Denne principielle enighed er dog forbundet med betydelige både praktiske og teoretiske problemer. Det drejer sig ikke bare om at opnå enighed om brugen af en ny term til et nyt fænomen eller om valg hhv. bortvalg af en af flere foreliggende fagtermer. Ønsker man fx en præference for internationalismer eller for nationalsproglige termer? Det er svært nok indenfor et enkelt sprog, men hvis det drejer sig om et internationalt samarbejde, bliver problemerne ikke mindre. Det har også været tilfældet under udarbejdelsen af NLO, Nordisk Leksikografisk Ordbog. Jeg vil her citere et brev fra Dag Gundersen, fra projektets koordinator til projektdeltagerne (sendt den 15.11.1996):

Vi bør absolutt jamføre dansk, bokmål og svensk og ha et fellesskandinavisk synspunkt for øye. Det ser ganske misvisende ut når ett av språkene går sine egne veier. Det betyr jo å si til leseren: I språket $\mathrm{x}$ er det umulig å gi termen den form den har i y og z. Jeg ber [...] og særlig [...] alvorlig overveie om det ikke kan finnes en felles form der det ikke er noen nå (felles form betyr ikke nødvendigvis lik skrive- 
måte). I det minste bør en felles form kunne sameksistere med den som er valgt fra før.

En slik felles form kan også komme i stand ved at den som representerer mindretallet, får aksept for at hans term er best også for de to andre språkene. Dette bør også vurderes.

I mit svar til Dag Gundersen gjorde jeg opmærksom på, at vi under hele forløbet med NLO aldrig havde været helt enige om en fælles nordisk linie. På grund af forskellige traditioner i de nordiske lande foreligger der forskellige grundholdninger, hvor man fx i Danmark i højere grad foretrækker internationalismer end man gør i Norge. Et eksempel er den for bokmål angivne term mellomspråklig ordbok, hvor vi på dansk har valgt interlingval ordbog, svensk har to ligeberettigede termer: mellanspråklig ordbok, interlingval ordbok, mens engelsk, fransk og tysk kun har hver en: interlingual dictionary, dictionnaire interlingue, interlinguales Wörterbuch. I andre tilfælde drejer uenigheden sig ikke så meget om internationalisme eller ej, men om termens relation til den leksikografiske definition. Her blev der for 'eksempel lavet af leksikografen' på bokmål valgt redaksjonseksempel, på dansk konstrueret eksempel, på svensk tilsvarende konstruerat exempel, på engelsk og fransk gives frit valg mellem flere muligheder: made-up example, editorial example hhv. exemple forgé, exemple construit, exemple fabri$q u e ́$, på tysk er der under hensyntagen til tysk tradition valgt Kompetenzbeispiel. Herfra vil jeg overlade det til NLOs anmeldere at tage stilling til de enkelte valg og ellers tilføje, at jeg ganske vist er enig i Dag Gundersens grundholdning, blot at den i praksis er svær at holde fast ved. I stedet for at fortsætte med dette og andre nutidige projekter vil jeg gå lidt tilbage i historien. Herved kan der lettere bevares en objektiv afstand til de enkelte problemer og til de implicerede lingvister, desuden kan man herved en passant afvise den besynderlige opfattelse, som gengives i GREIMAS/COURTÉS under lemmaet deskriptiv, at deskriptiv hhv. præskriptiv lingvistik udelukkende er et fænomen fra det 19. århundredes lingvistik, som i vores århundrede efter den generative transformationsgrammatiks opståen ikke mere skulle have nogen eksistensberettigelse. Vi går 350 år tilbage i tiden, til året 1640.

Ledelsen af ordenen, det "Fruchtbringende Gesellschaft", havde bedt et af dets medlemmer, Justus Georg Schottelius, om at give en bedømmelse af en tysk grammatik, som et af dets andre medlemmer, Christian Gueintz, havde skrevet. Nu var der det særlige ved situatio- 
nen, at Schottelius selv var i gang med at skrive en grammatik og derfor måske ikke var en helt uvildig bedømmer. I praksis brugte han lejligheden til at "overtage" en række af de teoretiske nyskabelser, som Gueintz var fremkommet med. Men ved selve sprogbeskrivelsen skete der ikke en tilsvarende overtagelse. I de to grammatikers sprogopfattelse foreligger der to modsatte holdninger: Guientz ville principielt rette sin sprogbeskrivelse efter det foreliggende sprogbrug, hvorimod Schottelius afviste at rette sig efter tilfældige sprogprøver, som kan være i modstrid med en systematisk fremstilling af regler og fænomener. Vi vil i dag tale om en deskriptiv contra en præskriptiv grundholdning. Mange af reglerne og de tilhørende eksempler stod i modsætning til "den rigtige grammatik", mente Schottelius i sit brev til selskabet fra den 26 marts 1640. Fx har Gueintz den regel, at substantiver, der som Kaiser (da. kejser) ender på -er, hedder det samme i ental og flertal. Det kan da ikke være rigtigt, siger Schottelius, man træffer ganske vist på nogen, som taler sådant. Men, skriver han, hvis man vil tale i overensstemmelse med grammatikken, så er det forkert: "wan man wil eigentlich und Grammatice reden, ists gar nicht recht." Hertil anfører han to grunde:

1. Ved hoffet og ved hoffets domstole har man tidligere tilføjet et -e i flertal, altså fx Keisere.

2. Hvis man ikke gjorde det, ville der kunne optræde uklarheder og unøjagtigheder. Fx ville man så ikke kunne se om der i sætninger die Könige und Keiser lagen $\mathrm{Zu}$ felde om det drejer sig om en eller flere kejsere, det kan man ved die könige und Keisere.

Gueintz svarede på kritikken samme år. Han ser ingen grund til at ændre noget som helst i sin sprogbeskrivelse, man laver reglen ud fra sprogbrugen og ikke sprogbrugen ud fra reglen (Guientz 1640):

Meine unvorgreifliche meinung ist, man laße Deutsch, deutsch bleiben. [...] der Gebrauch aber doch muß den anschlag geben vnndt nicht die Regel dem Gebrauch.

Derudover gør han opmærksom på, at ingen i dag mere taler som tidligere ved hoffets domstole. I øvrigt må man vide, tilføjer Gueintz, at man ikke kan ændre ethvert foreliggende sprogligt fænomen, sådan at alle udtryk bliver helt entydige.

Omkring hundrede år senere finder der en lignende diskussion sted, denne gang dog på en mindre aggressiv måde. Det drejer sig som udgiverens titel siger, om venlige stridsskrifter. Begge skrifters titel er i stil 
med datidens skik i sig selv program: "Vsus Tyrannus precario imperans" hedder det ene (Richey 1723). Forfatteren går ud fra den kendsgerning, at intet sprog i verden er medfødt, dvs. at ethvert menneske lærer sit sprog gennem efterligning af andres brug af dette sprog. Mange vil derfor ikke i deres ungdom høre "det sande, det egentlige sprog", og vil derfor kun kunne frembringe en "uklar, mangelfuld og endda forkert sprogbrug". På denne måde vil den allerdummeste pøbel, siger Richey, som i praksis udgør den største mængde, kunne sætte sig igennem med deres notorisk forkerte udtryk og talemåder. I stedet for at rette sig efter en sådan Usus Tyrannus skulle man hellere, mener Richey, løbende gennemføre sådanne forbedringer og forandringer, som ethvert fornuftigt menneske må kunne indse rigtigheden af.

Fabricius (1723) går i sin "Vsus imperium sine exceptione assertum" eller 'sprogbrugens uindskrænkede magt' ud fra en tese, som ved første blik minder om Richey's: Der findes ikke noget sprog, som er lavet efter en grammatik eller en ordbog, men grammatikken eller ordbogen er lavet udfra sproget. Sproget er lidt efter lidt opstået og har forandret sig i tidens løb på en række til dels helt tilfældige måder. Fabricius ser dog herudfra helt andre konsekvenser end Richey. En sådan ikke-styret sprogudvikling er ikke bare helt normal, men også på alle måder en fordel, mener Fabricius, idet sproget herved naturligt tilpasser sig nye tider og nye behov. I stedet for at doktorere på sproget, skal sprogvidenskabsmanden ændre sine beskrivelser i takt med ændringerne i sproget. Det kan man kun gøre, siger Fabricius, hvis man i udstrakt grad undersøger den foreliggende sprogbrug, både det lærde og det ikke-lærde sprog. Og hvis et bestemt ord eller talemåde regelmæssigt bliver brugt både i tale og skrift, så "wäre ich doch nicht befugt, dasselbige zu verwerfen, und schlechterdings zu verdammen.".

Som sagt blev denne diskussion ført yderst venskabeligt, men modsætningerne blev trukket stærkt op. Måske for stærkt. Fabricius har ganske vist et lettere overtag med lidt bedre argumenter for sin usus imperium end Richey med sit skrækbillede af usus tyrannus, da sidstnævnte ikke fortæller, hvordan eliten problemløst kan blive enige om at forbedre pøbelens angiveligt dårlige sprogbrug.

Ingen kan fordre, at et helt folk skulle antage en tyrans vilkårlige meninger for bindende regler, skriver Christian Molbech i forordet til sin ordbog til retskrivningens og sprogrigtighedens fremme fra 1813 . 
Molbech går principielt ud fra "Sprogbrugens Lovbog" også i forbindelse med fleksionsangivelser:

Saavidt en Ordbog tillader det, er ogsaa det Grammaticalske ved Ordenes rigtige Bøininger, Brug og Forbindelser oplyst; overalt efter Sprogbrugens Lovbog, og med Forkastelse af vilkaarlige Paafund og selvgiorte Regler hos Sproglærere. (Molbech, fortale, s. XI).

Hvor Molbech's og også Dansk Sprognævns nuværende grundholdning omtrent ligger på linie med Fabricius', svarer Richey's så nogenlunde til den, som længe har været førende i Norge, Island og på Færøerne.. Man kan således sige, at man i Danmark har tradition for at være mere deskriptiv end man har i Norge, eller omvendt, at man i Norge i højere grad tenderer til en præskriptiv sprogopfattelse end i Danmark. En sådan udtalelse dækker dog over store forskelle på forskellige områder og først og fremmest over, at termerne præskriptiv og deskriptiv bliver brugt af både lingvister og leksikografer på en temmelig uensartet vis. Det skal i det følgende påvises ud fra en række ordbogsartikler i totalsproglige og lingvistiske ordbøger.

\section{Præskriptiv og deskriptiv}

På mange måder er termerne deskriptiv, præskriptiv og normativ gode eksempler på, at den tyranniske brugs knopskydning og deraf følgende uensartethed har været stærkere end en række tyranners velmente og i princippet også nødvendige forsøg. Usus tyrannus har i dette tilfælde følgende facetter: Dels foreligger der konkurrerende termer med samme indhold. Det gælder præskriptiv ctr. normativ (i den betydning, som kan ses som antonym til deskriptiv), men dette punkt vil jeg her se bort fra og koncentrere mig om termerne deskriptiv og præskriptiv. Dels foreligger der ret forskellige definitioner af disse to termer.

Det er således ikke bare mangel på kendskab til lingvistisk historiografi, når der foreligger helt modsatte opfattelser om deskriptiv og præskriptiv og forskellige tiders lingvistik. Som allerede nævnt slog den deskriptive lingvistik ifølge GreIMAS/COURTÉs først igennem i det nittende århundrede, mens den i anden halvdel af vort århundrede er gået af brug og desuden skal have mistet sin eksistensberettigelse. Der findes også den helt modsatte opfattelse: Det 20. århundredes lingvistik er kendetegnet ved at være deskriptiv, hvorimod man i det 18. og 19. århundrede udelukkende eller fortrinsvis var præskriptiv (TRASK, HeUPEL). 
I alle opfattelserne findes der et fælles udgangspunkt, svarende til beskrivelsen i foreliggende mindre fremmedordbøger: deskriptiv betyder 'beskrivende', praeskriptiv 'foreskrivende'. Mere lingvistisk orienteret kan det også siges således: I en deskriptiv fremstilling stemmer beskrivelsen overens med de observerede data, i en præskriptiv fremstilling er en sådan overensstemmelse ikke nødvendig (TRASK). Derudover foreligger der en lang række forskelle.

Det er uklart, om deskriptiv bør anvendes som prædikat om både diakrone og synkrone fremstillinger. Så vidt jeg kan se, er det under påvirkning af den Amerikanske Strukturalisme, som i modsætning til den europæiske tradition ser deskription udelukkende som en mulighed $\mathrm{i}$ synkron fremstilling (CRYSTAL, GLÜCK). På den anden side er denne holdning kun logisk, hvis deskription på alle måder skal ses som en modsætning til præskription, som aldrig relateres til diakrone fremstillinger. Det har nu andre grunde, som jeg vender tilbage til.

Også påvirket af amerikansk tradition bliver deskriptiv forstået som en metode udelukkende eller især brugt til beskrivelse af eksotiske sprog, af sprog "uden egen litteratur og hidtil ubeskrevet af lingvistikken" (BoHUSCH). I samme tradition må man også se antagelsen af en nødvendig relation mellem deskription og en ren induktiv fremgangsmåde (HELBIG), som også medfører, at generelle udsagn ikke kan gives eller kun i indskrænket grad (GLÜCK).

De hidtil nævnte udtalelser kan afvises (Bergenholtz/Schaeder 1977 og Bergenholtz/Mugdan 1990), men de er med til at sløre billedet af de to virkeligt væsentlige problemområder i forbindelse med deskription ctr. præskription: Det drejer sig for det første om disse termers relation til 1. den antagede empiriske basis, 2. tekstreception, 3. tekstproduktion og 4. korrektur hhv. bedømmelse af foreliggende tekster. Disse fire punkter kan i relation til leksikografisk teori og praksis samles til to: Vi har for det første komplekset med en ordbogs empiriske basis (1) og for det andet ordbogsfunktioner (2, 3, 4).

En holdning som foretrukket af Richey bygger i en række tilfælde på en personlig bedømmelse, og ikke på nøjagtige gengivelser af sprogbrugsundersøgelser: "Prescriptive grammars are often based not on descriptions of actual language but rather on the grammarian's views of what is best." (LONGMAN). En sådan opfattelse må bygge på, at introspektion ikke regnes som empirisk basis, eller at lingvisten eller leksikografen vælger en angivelse, som (a) bevidst ikke gengiver den pågæl- 
dendes egen sprogkompetence, eller (b) ikke svarer til en adspurgt gruppes svar, eller (c) ikke stemmer overens med andre foreliggende beskrivelser, eller (d) ikke bygger på en analyse af tekstbelæg eller (e) ikke går ud fra en analyse af et tekstkorpus. Men det er ud fra det givne citat uklart, om en beskrivelse kan siges at være deskriptiv, hvis dens beskrivelse af det aktuelle sprog udelukkende bygger på (a). Principielt må man sige, at et udgangspunkt i hver af de nævnte muligheder kan betegnes som deskriptiv, men at man bør skelne mellem en større eller mindre grad af deskriptivitet (Bergenholtz/Mugdan 1990). Man vil da tilsvarende kunne skelne mellem forskellige typer af deskriptivitet.

Under forudsætning af en given teori eller mængde af teoretiske antagelser forstås deskription i det følgende som en fuldstændig gengivelse af samtlige empiriske data. Hermed menes, at hele materialet indgår i fremstillingen, dvs. at der ikke bevidst foretages udeladelser og ændringer. I relation til de ovenfor angivne grundmuligheder for valg af empirisk basis $(\mathrm{a}-\mathrm{e})$ kan der grundlæggende skelnes mellem:

deskription 1 (med udgangspunkt i introspektion)

deskription 2 (med udgangspunkt i multispektion, dvs. inddragelse af informanter)

deskription 3 (med udgangspunkt i allerede foreliggende beskrivelser uafhængig af disses empiriske basis)

deskription 4 (med udgangspunkt i belæg)

deskription 5 (med udgangspunkt i et tekstkorpus)

Hertil kommer, hvad der vil være den normale fremgangsmåde, forskellige kombinationer af to eller flere af disse deskriptionstyper.

Denne fuldstændige beskrivelse af den valgte empiriske basis vil muligvis ikke være den mest udbredte form for deskription. Mere sandsynligt er det, at der foretages en udvælgelse på en sådan måde, at visse sproglige fænomener, som forekommer sjældent eller af andre grunde antages at være ikke-relevante, ikke medtages i beskrivelsen. Hermed menes ikke, at disse fænomener afvises eller forbydes, de nævnes blot ikke. Som eksempel på denne type kan følgende artikel med præpositionen entsprechend (da. 'svarende til') fra DUDEN 10:

entsprechend <Präp. mit Dativ> [...] e. seinem Vorschlag, seinem Vorschlag e. 
Præpositionen styrer altså - ifølge denne ordbog - dativ og kan være for- eller efterstillet. Den første oplysning gives eksplicit, de to sidste implicit i form af kollokationsangivelser. Men det nævnes ikke, at entsprechend også bruges med genitivrektion, og derfor heller ikke, om præpositionen i disse tilfælde kan være både for- og efterstillet. Deskriptivt set mangler der således halvdelen af de strukturelle muligheder, men kun ca. 3\% af foreliggende belæg med entsprechend (Bergenholtz 1984, 18).

Denne form for deskriptiv ufuldstændighed er både i grammatikografien og i leksikografien udbredt og kan beskrives som en selektiv deskription, der sker bevidst eller ubevidst. Den skal her kaldes proskription. Svarende til argumentationen og opdelingen ovenfor i forskellige typer af deskription kan der skelnes mellem proskription 1, 2, 3, 4, 5 og kombinationer af to eller flere af disse muligheder. Man må her skelne mellem en svagt proskriberende fremgangsmåde, en stærkere proskription og en maksimal proskription, som altid kun tillader en af de muligheder, som deskriptivt kan påvises.

Præskription hhv. normering forstås i denne sammenhæng som synonymer, det gælder også for de hertil hørende adjektiver præskriptiv og normativ. Her kan der skelnes mellem følgende typer:

præskription 1 (et givet sprogligt fænomen forbydes eksplicit)

præskription 2 (et bestemt allerede foreliggende sprogligt fænomen påbydes eksplicit, ofte forbundet med præskription 1)

præskription 3 (denne type minder om præskription 2, men adskiller sig fra denne ved at skabe en ny term, en ny skrivemåde, en ny udtale eller en anden form for nyskabelse, sml. Wiegand 1996)

præskription 4 (en maksimalt præskriptiv ordbog, dvs. en ordbog, som ud fra præskription 2 og til dels præskription 3 i hvert enkelt tilfælde kun tillader/angiver en term med en og kun en grammatisk brug)

\section{Forslag til leksikografisk praksis}

Hvis man prøver at finde en ordbog, som svarer til en af de her definerede former for deskription, proskription eller præskription, vil man kunne påvise, at de fleste ordbøger typologisk set må betegnes som pri- 
mært proskriptive. Rent deskriptive ordbøger kendes især ved forfatterordbøger (deskription 4 eller 5) eller frekvensordbøger (deskription 5). Rent præskriptive ordbøger findes kun i ringe grad, hvis der dermed menes, at der ved samtlige artikler er gået ud fra principper som beskrevet for præskription 1, 2, 3. Ofte vil det være sådan, at en ordbog, der af dens forfattere beskrives som en præskriptiv ordbog, kun i nogen grad vil indeholde angivelser, som er eksplicit præskriptive. I en typisk præskriptiv almensproglig ordbog, i en "sprogrigtighedsordbog" (SPRACHSCHWIERIGKEITEN) har jeg under bogstavet $\mathrm{K}$ fundet følgende præskriptive prædikater:

muß stehen

muß verwendet werden

nicht zulässig

nur

sollte nicht gefördert werden

sollte vermieden werden

Sml. hertil følgende ordbogsartikel:

konsultieren [...] Die reflexive Form sich mit jmdm. konsultieren sollte vermieden werden, da die Wechselbeziehung vom Verb nicht erfaßt wird. Statt dessen: sich mit jmdm. beraten

Men langt hyppigere forekommer prædikater, som kan betegnes som deskriptive eller proskriptive alt efter sammenhængen (ordnet efter hyppighed):

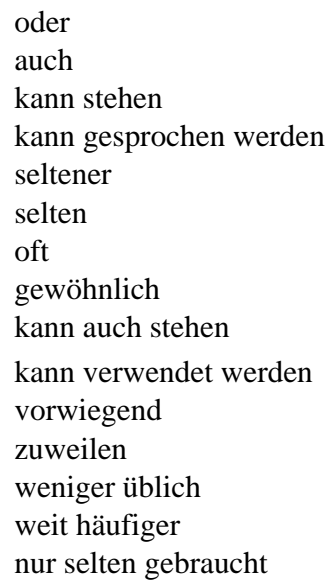


Det interessante ligger i grunden ikke $\mathrm{i}$ at påpege tendenser, som så kan bruges til at fremhæve den ene eller den anden kæphest hhv. hverve partigængere til Fabricius og Richey's grundholdninger. Det leksikografisk relevante vil være, hvis der kan påvises nogle brugerbehov, som kan tale for at koncipere en primært deskriptiv, primært proskriptiv eller primært præskriptiv ordbog. Eller sagt på en anden måde: Mindst ligeså afgørende som beskrivelsens grundlag er beskrivelsens genuine formål. Ofte antages en nødvendig gensidig forekomst af på den ene side en præskriptiv målsætning og produktionsregler og på den anden side deskription og analyseregler (HEUPEL). Noget mindre bombastisk kan man også sige det sådan, at en præskriptiv ordbog vil påvirke sprogbrugen, hvad en deskriptiv ordbog ikke intenderer at gøre (NLO). Denne intention kan imidlertid ikke holde stand i praksis, hvad NLO også gør opmærksom på, idet man må gå ud fra deskriptionens normative kraft (Wiegand 1986). En ordbogsbruger, som søger oplysning i en ordbog, når han har et tekstproduktionsproblem, får jo en oplysning, som vanskeligt kan forstås som andet end en ønsket påvirkning. Forskellen mellem en maksimalt præskriptiv ordbog (præskription 4) og en maksimalt deskriptiv ordbog (deskription 5) vil i relation til tekstproduktion hhv. reception dels være, at den præskriptive ordbog mere entydigt giver råd ved produktionsproblemer, hvor en deskriptiv ordbog ofte giver næsten frit valg mellem en række muligheder. Dels vil det være sådan, at den maksimalt præskriptive ordbog vil være mindre egnet ved receptionsproblemer, idet den ikke optager alle forekommende leksemer i alle forekommende varianter. Et eksempel på en proskriptiv ordbogsartikel fra den danske retskrivningsordbog, som står tydelig i den tradition, vi allerede har mødt hos Molbech:

leksikon -et, -er $e l$. leksika, $b f$. $p l$. leksikonerne $e l$. leksikaene

Det er i forhold til sprogreception hhv. korrektur af foreliggende tekster en liberal holdning, som tillader plural ubestemt form leksikoner eller leksika og bestemt form leksikonerne og leksikaene (men ikke *leksikonner). I forhold til sprogproduktion er det en såre lident hjælpsom angivelse, som ikke giver svar på, hvad jeg bør vælge, eller hvad man normalt vælger. Denne holdning er så liberal, at man endda giver frit valg mellem ord, som i faglig sammenhæng er helt forskellige, fx i RTO:

retlig (el. retslig)

retslig (el. retlig) 
Ved retlig menes en tilknytning til retsordenen, ved retslig en tilknytning til myndigheder, der administrerer retsordenen. Man kan også se, at der foretages forskellige ækvivalentangivelser ved oversættelse til andre sprog, fx til tysk retlig $\rightarrow>$ rechtlich, retslig $\rightarrow$ gerichtlich. Her er den i Danmark foretrukne deskriptiv/proskriptive grundholdning i virkeligheden blevet præskriptiv (svarende til præskriptiv 3), idet en foreliggende fagligt fastlagt betydningsadskillelse ophæves. Noget helt andet er, at jurister indtil nu ikke ser ud til at have taget notits af den overflødige indblanding i juridisk sprogbrug.

Denne danske grundholdning viser sig ikke kun i almensproglige ordbøger, men også i holdningen til fagordbøger. Konkret er jeg fx blevet kontaktet af en dansk fagleksikograf, som af sit forlag var blevet bedt om at stryge en præskriptiv tilføjelse: "det kan diskuteres, om det er en ordbogs opgave at fælde dom over sprogbrugen”. I det pågældende tilfælde havde leksikografen advaret mod en blandt lægfolk udbredt, men fagligt ukorrekt brug af en term. Svaret til forlaget blev efter samtalen følgende: "Det er i høj grad en fagordbogs opgave at oplyse om korrekt brug af fagsproget, også fordi det jo netop også er det, som brugeren søger information om.” Måske er det pågældende danske forlag ikke uden videre typisk, men det er nok sværere at forestille sig, at en sådan udtalelse ville kunne være kommet fra et norsk eller et islandsk forlag. Så vidt som jeg har fulgt diskussionen i disse lande, har problemet her snarere været, at optagelse af bestemte internationalismer har kunnet vække anstød.

Hvis en ordbog skal konciperes som en polyfunktional ordbog, vil jeg her foreslå en fremgangsmåde i form af en kombination af deskription 1, 4 og 5 med præskription 1, 2 og 3 eller en kombination af proskription 1, 2 og 5 med præskription 1, 2 og 3, sml. hertil eksempel med førstnævnte kombination under ja i Bergenholtz/Mugdan (1984), med sidstnævnte kombination under virus i GENTEKNOLOGISK ORDBOG.

Der bør således i en spansk ordbog både optages den "spanske" term $A D N$ i lemmabestanden, men også den internationale hhv. engelske term $D N A$, idet sidstnævnte regelmæssigt bruges på spansk (i 1 mio. tekstord 1200 belæg med DNA mod 2400 med ADN). Derimod kan og bør der gives forslag til sprogproduktion hhv. oversættelse, det kan fx gøres ved at have den ikke-anbefalede term som henvisningslemma og den anden som lemma i en artikel med alle nødvendige angivelser (praksis i Kaufmann/Bergenholtz). Det er også den metode, som er 
blevet anvendt i NLO. Her er der anvendt en dobbeltpil (=>) fra forekommende termer til de termer, der anbefales, sml. her fx direkte henvisning og indirekte henvisning. Der har som ovenfor nævnt med udgangspunkt i forskellige traditioner været enkelte forskelle, men principielt har der under udarbejdelsen af NLO været enighed om at tilslutte sig Jacob Grimms tese: "en ordbog er ikke til for at tie om ord, men for at fortælle om dem". Således har vi på trods af nogle betænkeligheder valgt at anføre både et lemma lemmatisering 1 'det at ordformer som hører til samme leksem, blir samlet under samme lemma' og et lemmatisering 2 'det at et ords oppslagsform tas opp som lemma'. Trods berettigede indvendinger mod en deraf manglende entydig terminologi må denne fremgangsmåde være mere fordelagtig ved receptive problemer, end en ufuldstændig gengivelse af foreliggende sprogbrug. Det er fx tilfældet i VARME TERMER, hvor definitionen ikke tager højde for, om man ved fleksionsformer af samme leksikonord kan tale om samme leksem, sml. gå, går, gik, gået:

ord enhed i tekstforløbet af et eller flere sammenkædede morfemer der i skriften adskilles af spatium (blanktegn). Et ord består altid af mindst én rod, men der kan være flere rødder (i en sammensætning), og der kan være tilføjet afledningselementer og bøjningselementer, fx Peter, sang-er, hoved-bane-gård-en-s.

Forskellige løbende ord, der staves ens, er samme leksem (leksikalske ord). Fx forekommer leksemet $o g$ fem gange (som fem løbende ord) i Der er for langt mellem kød og og og og og flaesk.

Hvor en rent deskriptiv oplysning - som de grammatiske angivelser ved eksemplet leksikon - ikke giver hjælp til sprogproduktion, giver en for proskriptiv eller ekstrem præskriptiv artikel en for indskrænket hjælp til tekstreception.

Man kan muligvis ikke helt undgå at vække anstød - hverken i sprogbrug eller ved ordbogsproduktion - men man er ikke tvunget til at vælge at være tilhænger af enten Richey eller Fabricius. Man kan under hensyntagen til en ordbogs genuine formål vælge en samtidig deskriptiv og præskriptiv eller en samtidig proskriptiv og præskriptiv fremgangsmåde. Forekomster af forskellige fleksionsformer af fnise i det undersøgte tekstkorpus fordeler sig på følgende måde:

fnise 7

fniser 11

fnisede 37 
fniste 12

fnes 2

fniset 4

fnist 0

RTO har valg en ret unøjagtig deskriptiv fremstilling:

fnise, -ede $e l$. -te $e l$. fnes, fniset $e l$. fnist.

Om det her drejer sig om deskriptiv 1, 2, 3, 4 eller 5 eller en form for kombination, er uklart. Set ud fra en brugers synspunkt er den uklare deskription udmærket, hvis bogen skal bruges som rettesnor for korrektion: Meget tillades. Hvis bogen skal bruges som hjælp ved sprogproduktion af en bruger, der først og fremmest vil have hurtig hjælp, er den upraktisk, fordi den overladen valget til brugeren. Det kunne en proskriptiv fremstilling havde rådet bod på, fx på følgende måde:)

fnise $-r$, $-d e,-t$

Men også en deskriptiv fremstilling efter deskriptiv 5 ville hjælpe, fx

fnise præs: -r, præt: -de (hyppig) eller fniste (sjældnere) eller fnes (sjælden), perf part -t (hyppig) eller fnist (meget sjælden)

Disse angivelser kunne gives med absolutte tal:

fnise præs: -r, præt: -de (37) eller fniste (12) eller fnes (2), perf part -t (4) eller fnist (0)

Endnu mere nøjagtig ville en hensyntagen til kønsfordelingen være, idet man først og fremmest om piger og kvinder vil sige, at de fnisede. Hvis drenge eller mænd undtagelsesvis har gjort det, siger man, at de fniste, sml. følgende belæg:

Din bror hjalp hende gennem de svære måneder," forklarer han og kaster hovedet tilbage og ler overdøvende. Så begynder Abel også og Tina kommer ind med en lille bakke med kaffekande, flaske og glas og spørger hvorfor de griner. Og begynder selv at fnise.

Vi kunne også have fået en præskriptiv ordbogsartikel, som indholdsmæssigt ville kunne svare til en proskriptiv artikel (forstået som et begrundet udvalg fra en deskriptiv undersøgelse), men som også være i modstrid med deskriptive tendenser, $\mathrm{fx}$ :

fnise $-r$, fnes, fneset 
Et af de andre nævnte tilfælde med variantrigdom var misbrug, her giver en korpussøgning følgende resultater:

misbruget 10

misbrugen 0

et misbrug 6 (et groft seksuelt misbrug, ryge ud i et misbrug)

en misbrug 1 (er klart en misbrug af afstemningen)

RTO er således udmærket egnet som rettesnor for en skolelærer, der ikke behøver at anse alt for forkert, men er ikke en klar rettesnor ved produktionsproblemer. Det ville en meget enklere proskriptiv angivelse være:

misbrug et, -et, -, -ene

Særligt tydelig bliver diskrepansen mellem en unøjagtig deskriptiv holdning og behovet for hjælp til sprogproduktion ved substantiver som aften og morgen: Skal man nu skrive aftenen eller aftnen? RTO giver frit valg. Den foreliggende sprogbrug, som en sprogbruger som regel ikke ønsker at afvige fra, er derimod meget entydig:

aftenen 721

aftenens 84

aftnen 3

aftnens 0

aftener 98

afteners 1

aftner 7

aftners 0

aftenerne 11

aftenernes 1

aftnerne 3

aftnernes 0

morgenen 388

morgnen 4

morgener 23

morgner 0

morgenerne 6

morgnerne 0

En proskriptiv ordbog til sprogproduktion kunne have følgende arikler: 
morgen en, -en, -er, -erne

aften en, -en, -er, -erne

Sådanne artikler vil være præskriptive, hvis de forbyder andre former enten ud fra ordbogens fortekst eller eksplicit i artiklen:

morgen en, morgnen, morgner, morgnerne, ikke: morgenen, morgener, morgenerne

eller

aften en, -en, -er, -erne, ikke: aftnen, aftner, aftnerne

Deskriptive artikler vil kunne bygges op efter samme læst som prøveartiklerne med misbrug, enten med relative eller absolutte hyppighedsangivelser.

På lignende vis vil kunne argumenteres i følgende tilfælde:

publikummet 13 / publikumet 0

katalogen 2 / kataloget 15

bægret 6 / bægeret 36, bægre 25 / bægere 0 , bægrene 4 / bægerne 2

nævnede 10 / nævnte 247

menneskerne 7 / menneskene 124

kratre 0 / kratere 7, kratrene 0 / kraterne 137

en sammenhæng 112 / et sammenhæng 1, sammenhængen 34 / sammenhænget 0 , (ubest. plur.) sammenhænge 40 / sammenhæng 0

Ud fra disse empiriske data kunne en ordbogsartikel beregnet til skriftlig sprogproduktion have følgende enkle fleksionsangivelser:

sammenhæng en, -en, -e, -ene

Hvis man vil være imødekommende overfor den lovgivende magt kunne man tilføje, at mere er tilladt, men at man ikke anbefaler det:

sammenhæng en, -en, -e, -ene Dansk Sprognævn godtager også plur sammenhæng og desuden intetkøn: et sammenhæng

Sprogbrugen for kursus er endnu entydigere:

kurset: 28

kurser: 75

kurserne: 16

kursusser: 0

kursuserne: 0 
kursussene: 0

kursussene: 0

kursusset: 0

kursuset: 0

En proskriptiv og samtidig lovlydig ordbogsartikel kunne have følgende form:

kursus et, kurset, kurser, kurserne Dansk Sprognævn godtager også kursuset/kursusset, kursus, kursusene/kursussene

I de tilfælde, hvor korpusmængden ikke er tilstrækkelig, vil man kunne drage analogislutninger, så alle følgende ordbogsartikler vil kunne svare til:

middel et, midlet, midler, midlerne Dansk Sprognævn godtager også middelet

midlet $16 /$ middelet 0

musklen 3 / muskelen 0

strimlen 6 / strimmelen 0

møblet 3 / møbelet 0

kitlen 7 / kittelen 0

kartoflen 0 / kartoffelen 0

hvirvlen 1 / hvirvelen 0

cirklen 10 / cirkelen 0

kuplen 16 / kuppelen 1

længslen 9 / længselen 2

manglen 22 / mangelen 4

reglen 62 / regelen 6

Ikke i alle tilfælde kan der foreslås en bestemt variant. Af og til er sprogbrugen særlig usikker, og så vil også en proskriptiv fremgangsmåde være nødt til at forudse varianter, sml. resultatet af korpussøgning med foreslået ordbogsartikel:

forbudet 26 / forbuddet 24 , forbudene 1 / forbuddene 1

forbud et, et/det, -, ene/dene

Et lettere brugbart svar for den, som er usikker, er dog et entydigt svar, som ikke overlader valgmulighederne til den, der netop søger hjælp. Og her er normal sprogbrug faktisk lige så pietetsløs og hadefuld, som de formodede kritikere af en god gammel sprogbrug er: 
i steden for 0

i stedet for 705

Man kan efter behov prøve at indsætte "i steden for" i stedet for "i stedet for" i følgende belæg fra skriftlige tekster. Måske ikke i mundtlig sprogbrug, men i skriftlige tekster, virker resultatet forkert

Han blev souschef for radioen i stedet for Per Stig Møller, der valgte at koncentrere sig om folketingsarbejdet.

Alt for mange kvinder begår den fejl at se sig om efter mænd, de kan udvikle et forhold til - i stedet for først at udvikle sig i forholdet til sig selv.

Kongemagten og kirken er de gamle institutioner, som man igen skal samles om i stedet for det nye demokrati, som kun har ført landet ud i en national krise.

I RTO finder man under lemmaet sted følgende angivelser: sted -et, -er [...] i stedet (el. i steden) for [...]

I en deskriptiv ordbogsartikel burde denne artikel ændres til: sted -et, -er [...] i stedet for (i steden for bruges kun i talt sprog) [...]

I en præskriptiv ordbogsartikel kunne man i stedet nøjes med: sted -et, -er $[\ldots]$ i stedet for $[\ldots]$

\section{Litteratur}

\section{Ordbøger}

$\mathrm{AHD}=$ The American Heritage Dictionary. 2. udg (rev. udg. af The American Heritage Dictionary of the English Language). Boston: Houghton Mifflin Company 1976.

BoHUSCH = Otmar Bohusch: Lexikon der grammatischen Terminologie . Donauwörth: Auer 1972.

CRYSTAL = David Crystal: A Dictionary of Linguistics and Phonetics. Third Edition. Oxford: Blackwell 1991.

Duden $10=$ Duden. Bedeutungswörterbuch. 24000 Wörter mit ihren Grundbedeutungen. Bearb. von Paul Grebe, Rudolf Köster, Wolfgang Müller u. w. Mitarbeitern der Dudenredaktion: Mannheim/Wien/Zürich 1985.

GENTEKNOLOGISK ORDBOG = Uwe Kaufmann/Henning Bergenholtz: Genteknologisk ordbog. Dansk-engelsk/engelsk-dansk molekylarbiologi og DNA-teknologi. København: Gad 1992. 
GLÜCK $=$ Metzler Lexikon Sprache. Hrsg. von Helmut Glück. Metzler: Stuttgart/ Weimar 1993.

GReIMAS/COuRTÉS = Algirdas Julien Greimas/Joseph Courtés: Semiotik. Sprogteoretisk ordbog. Dansk redaktion: Per Aage Brandt og Ole Davidsen. Århus: Aarhus Universitetsforlag 1988.

HeLBIG = Gerhard Helbig: Kleines Wörterbuch linguistischer Termini. Beilage zur Zeitschrift "Deutsch als Fremdsprache" 2/1969. Dresden: Verlag Zeit im Bild 1969.

HEUPEL = Carl Heupel: Taschenwörterbuch der Linguistik. München: List 1975.

KAUFMANN/BERGENHOLTZ = Uwe Kaufmann y Henning Bergenholtz con cooperación de Bjarne Stumman, Sven Tarp, Laura de la Rosa Marabet, Nelson la Serna Torres y Gladys la Serna Miranda: Diccionario Enciclopédico de Ingeniería-Genética Español-Inglés. Toronto: Lugus 1997.

LONGMAN $=$ Jack C. Richards/John Platt/Heidi Platt: Dictionary of Language Teaching \& Applied Linguistics. Second Edition. Harlow: Longman 1992.

MolbeCH $=$ Christian Molbech: Dansk Ordbog indeholdende det danske Sprogs Stammeord, tilligemed afledede og sammensatte Ord, efter den nuvarende Sprogbrug forklarede $i$ deres forskiellige Betydninger, og ved Talemaader og Exempler oplyste. Kiöbenhavn: Paa den Gyldendalske Boghandlings Forlag 1833.

NLO = Henning Bergenholtz/Ilse Cantell/Ruth Vatvedt Fjeld/Dag Gundersen/Jón Hilmar Jónsson/Bo Svensén: Nordisk leksikografisk ordbog. Oslo: Universitetsforlaget 1997.

RTO = Dansk Sprognævn: Retskrivningsordbogen. 2. udgave. København: Aschehoug 1996.

SPRACHSCHWIERIGKEITEN $=$ Joachim Dückert/Günther Kempcke (Hrsg.): Wörterbuch der Sprachschwierigkeiten. Zweifelsfälle, Normen und Varianten im gegenwärtigen deutschen Sprachgebrauch. Leipzig: VEB Bibliogr. Inst. 1984.

TRASK $=$ R.L.Trask: A Dictionary of Grammatical Terms in Linguistics. London/New York: Routledge 1993.

VARME TERMER = Jens Cramer/Lars Anton Henriksen/Mette Kunøe/Erik Vive Larsen/Ole Togeby/Peter Widell: 699 varme termer. Leksikon til sprogkundskab. Århus: Aarhus Universitetsforlag 1996.

\section{Sekundærlitteratur}

Bergenholtz, Henning (1984): Grammatik im Wörterbuch: Syntax. In: Studien zur neuhochdeutschen Lexikographie V, hrsg. von Herbert Ernst Wiegand. Hildesheim/ New York: Olms, 1-46.

Bergenholtz, Henning (1998): Deskriptiv, proskriptiv og præskriptiv leksikografi. In: Normer og regler. Festskrift til Dag Gundersen 15. januar 1998, red. av Ruth Vatvedt Fjeld og Boye Wangensteen. Oslo: Nordisk forening for leksikografi, 233246. 


\section{8}

Bergenholtz, Henning/Joachim Mugdan (1984): Grammatik im Wörterbuch: von ja bis Jux. In: Studien zur neuhochdeutschen Lexikographie V, hrsg. von Herbert Ernst Wiegand. Hildesheim/New York: Olms, 47-102.

Bergenholtz, Henning/Joachim Mugdan (1990): Formen und Probleme der Datenerhebung II: Gegenwartsbezogene synchronische Wörterbücher. In: Wörterbücher. Dictionaries. Dictionnaires. Ein internationales Handbuch zur Lexikographie. Zweiter Teilband, hrsg. von Franz Josef Hausmann/Oskar Reichmann/Herbert Ernst Wiegand/Ladislav Zgusta. Berlin/New York: de Gruyter, 1611-1625.

Bergenholtz, Henning/Burkhard Schaeder (1977): Deskriptive Lexikographie. In: zeitschrift für germanistische linguistik 5.1, 2-33.

Fabricius, Johann Albert (1723): Usus imperium sine exceptione assertum oder die unumschränkte Gewalt des Gebrauchs/gleichwie in andern Sprachen/also auch in der Teutschen, behauptet wider die weit aussehenden Neuerungen der SprachLehrenden Malcontenten. In: C.F. Reichmanns Poesie der Nieder-Sachsen. Zweyter Theil. Dem vorgedruck einigen zwischen Herrn Doct. Fabricius und Herrn Prof. Richey freundlich-gewechselte Streit-Schriften über verschiedene, die Teutsche Sprache betreffende, Puncte. Hamburg: Johann Christoph Kißner 1723, 12-26. (= Poesie der Niedersachen. Hrsg. von Christian Friedrich Weichmann 1721-1738. Bd. 2. Unveränderter Nachdruck: München: Kraus Reprint 1980)

Gröschel, Bernhard (1982): Sprachnorm, Sprachplanung und Sprachpflege. Bibliographie theoretischer Arbeiten aus Linguistik und Nachbarwissenschaften. Münster: Institut für Allgemeine Sprachwissenschaft der Westfälischen Wilhelms Universität.

Gueintz, Christian: [Entgegnung von Gueinzius, 1640]. Abgedruckt in: Der Fruchtbringenden Gesellschaft ältester Ertzschrein. Briefe, Devisen und anderweitige Schriftstücke. Urkundlicher Beitrag zur Geschichte der deutschen Sprachgesellschaften im 17. Jahrhundert. Leipzig: Dyk'sche Buchhandlung 1855: 253-257. Nachdruck: Hildesheim/New York: Olms 1973.

Gueintz, Christian (1641): Deutscher Sprachlehre Entwurf. Köthen.

Hansen, Erik (1997): Topti-listen. In: Mål \& Male 3, 20 årg., 29-31.

Nielsen, Hans Jakob (1997): Former, der vækker anstød. In: Jyllands-Posten, søndag den 9. februar 1997.

Richey, Michael (1723): Usus Tyrannus precario imperans, oder Vernunft-mäßige Sätze von der Gewalt des Gebrauches in den Sprachen/insonderheit in der Teutschen, ingleichen ob und wie weit man demselben durch Regeln der SprachKunst Einhalt thun könne. In: C.F. Reichmanns Poesie der Nieder-Sachsen. Zweyter Theil. Dem vorgedruck einigen zwischen Herrn Doct. Fabricius und Herrn Prof. Richey freundlich-gewechselte Streit-Schriften über verschiedene, die Teutsche Sprache betreffende, Puncte. Hamburg: Johann Christoph Kißner 1723, 2-11. (= Poesie der Niedersachen. Hrsg. von Christian Friedrich Weichmann 1721-1738. Bd. 2. Unveränderter Nachdruck: München: Kraus Reprint 1980). 
Schottelius, Justus Georg: [Des Schottelius Gutachten über des Ordnenden Sprachlehre, 1640]. Abgedruckt in: Der Fruchtbringenden Gesellschaft ältester Ertzschrein. Briefe, Devisen und anderweitige Schriftstücke. Urkundlicher Beitrag zur Geschichte der deutschen Sprachgesellschaften im 17. Jahrhundert. Leipzig: Dyk'sche Buchhandlung 1855, 246-253. Nachdruck: Hildesheim/New York: Olms 1973.

Schottelius, Justus Georg (1641): Teutsche Sprachkunst. Abgetheylet in drey Bücher. Braunschweig.

Wiegand, Herbert Ernst (1986): Von der Normativität deskriptiver Wörterbücher. Zugleich ein Versuch zur Unterscheidung von Normen und Regeln. In: Sprachnormen in der Diskussion. Beiträge vorgelegt von Sprachfreunden. Berlin/New York: de Gruyter, 72-101.

Wiegand, Herbert Ernst (1996): Über usuelle und nichtusuelle Benennungskontexte in Alltag und Wissenschaft. In: Clemens Knobloch/Burkhard Schaeder (Hrsg.): Nomination - fachsprachlich und gemeinsprachlich. Opladen: Westdeutscher Verlag, 55-103. 
